\title{
A New Perspective on Covid-19 Treatment: When a Paradigm Changes in Infectiology Become Necessary against an Emerging Virus as the SARS-Cov2
}

\section{Louis Sylvain Peng-wende Ouedraogo ${ }^{1, *}$, Sodjehoun Apeti ${ }^{2}$ and Dieudonné Ouedraogo $^{3}$}

1 MD geriatrician at covid19 unit, infectiology department; hospital center of lens (France);

2 MD geriatrician at internal medicine department; academic hospital center sylvanus olympio (Togo); j.raphaelapeti@yahoo.fr

${ }_{3}$ MD professor rheumatologist head of service of rheumatology; academic hospital center bogodogo (Burkina Faso); ouedd@yahoo.fr

* Correspondence author: sylvainouedraogo@gmail.com; Tel: 0033640909288, postal adress: 73 gilbert facq street road at ostricourt, postal code 59162, France

\begin{abstract}
Background \& Aims: The covid19 is a world changing challenge. Furthermore, this disease challenges our capacities to change our point of view in the domain of infectiology, immunology and global public health. Many trials try some drug such as antiviral (lopinavir, remdesivir) interferon, and the chloroquine. Unfortunately, all approach is not really convincing at this time. We are proposing another approach on this issue. In infectiology there are two protagonists: the host and its immune system versus pathogens and its virulence. Our approach focuses on an intervention on the host's immune system and how stimulate and modulate its reactions. Methods: We searched on PubMed and Google Scholar databases for French and English-language studies, without a limit of date of publications, for randomized clinical trials, meta-analyses, reviews, systematic reviews, observational studies, case report. We performed a review on the field of immunology enhancements by nutrients use. Results: We identified groups of vitamins (D and C), oligo-elements (magnesium, zinc, selenium) and nutrition advice which enhance immune system response. Indeed, these supplements have some proved properties in modulating and stimulating the immune system. For example, a recent study demonstrates that vitamin D deficiency is linked with the severity of covid19. Majority of the population has a deficiency in these elements. According to this, we propose a therapeutic protocol using these elements to reach an efficient therapy against covid19 by enhancing host's immune system. Conclusion: Due to this serious pandemic, any solutions must not be disregarded. The nutrition way is an entire part of the solution.
\end{abstract}

Keywords: covid19; immunostimulant; immunomodulator; vitamin D; vitamin C; zinc

\section{Introduction}

Since December 2019, a cluster of unknown pneumonia disease appears in Wuhan caused by a news coronavirus: the SARS-COV-2 [1-2-3]. Then March 11, 2020, the general director of world health organisation (WHO) declare the pandemic of covid19[4].

Since Louis Pasteur's findings on micro-organisms[5] and Alexander Fleming[6] with his discovery of penicillin in the eighteen centuries; the infectiology principle does not change a lot. Indeed, the main strategy in infectiology is to identify pathogens and to fight them with drugs. Another strategy used is to train immune system with vaccination to avoid the expansion of 
infection[7]. Therefore many trial starts to find an efficient therapeutic against covid19 [8-9] using some molecules: Remdesivir, Lopinavir/Ritonavir Lopinavir/Ritonavir plus interferon ß-1a, Hydroxychloroquine. All trials[10], while promising, have not yet proved their effectiveness.

We propose a new therapeutic approach, a new paradigm in the field of infectiology face to sarscov-2. The host immune system and virulence of the pathogen are the two competing elements in infectiology. Face to sars-cov-2, we noticed that all solutions respecting this principle have remained unsuccessful for the moment. Why not take the opposite way and focus our actions on the host's immune system to win the fight? Why not stimulate and modulate the immune system's response to make it more effective against sars-cov-2. Mostly, we know that the main complication of the disease is related to the development of a thrombogenic pro-inflammatory ground [11-12] and the cytokine storm[13]. These complications are all related to dysfunction of the immune system. For this reason, it seemed logic to focus research on the stimulation and modulation of the immune system to avoid this disaster. Good nutrition, vitamins and oligo-elements play an important role in immune system enhancement[14].

\section{Materials and Methods}

We searched on PubMed and Google Scholar databases for French and English-language studies, without a limit of date of publications, for randomized clinical trials (RCT), meta-analyses, reviews, systematic reviews, observational studies, case report. A first look with the terms: immunity, immune system, immuno-stimulant, immune-modulator, a second look with the terms: immune system AND (vitamin C OR vitamin D OR zinc OR selenium OR nutrition); then a third look with the terms: covid19 AND (vitamin C OR vitamin D OR zinc OR selenium OR nutrition). Emphasis was given to more recent RCT, systematic reviews and meta-analyses.

\section{Results}

\subsection{Influence of latitude and climate}

Many studies were interested in the repartition of respiratory virus outbreak in the world[1516]. The epidemics of this virus seem to respect a certain latitude [17-18] and seasonality around the world. Indeed, we remark that influenza and coronavirus outbreak occurs, in north hemisphere at winter[16]. In tropical areas it seems that outbreak occurs when it is humid-rainy condition during rainy season [19]. The peak is less important than temperate one[18]. This demonstrates that the environment plays an important role in the outbreak and spread of this kind of disease. Therefore, we need to be aware of an upsurge of covid19 spread in tropical areas as rainy season approach towards June -July. According to the precedent SARS-CoV outbreak[16], which occur in winter, it is possible think that this SARS-CoV-2 will have the same seasonality.

Studies show that seasons play a certain role in the virulence of the virus and host immunity[16]. Indeed, the temperature and humidity of air breathing can accelerate the replication of the virus in airway. Furthermore, the climate plays a role on host innate immunity in decrease phagocytose and maturation of macrophage granulocyte monocyte according to daylight period and vitamin $\mathrm{D}(\mathrm{VD})$ rate[16-20]. Thus, we see that southern people have a lower mortality level from covid19 because to their level of VD[21].

\subsection{Immunostimulant and immunomodulation therapy}

\subsubsection{Role of vitamin D}

The classical role of VD is known in phosphor-calcic homoeostasis and bone turnover[22]. VD is brought to the body, $20 \%$ by diet intake and $80 \%$ skin synthesis; then is transformed to its biological active form in 25(OH)D3 by enzymes cytochrome P450 2R1 and P450 27 into liver[23-24] . Then the fully active metabolite $1.25(\mathrm{OH}) \mathrm{D} 3$ is hydroxylate in the kidney by the enzyme CYP27B1[25]. However, CYP27B1 is expressed by other cells as immune system cells, and the activity of CYP27B1 is controlled by inflammatory signals, such as lipopolysaccharide cytokines, unlike kidneys. 
A consensus of experts proposes a rate between 20 to $125 \mathrm{nM} / \mathrm{L}$ to avoid skeletal complications, without toxic effect[23-25]. Moreover, the mortality related to $25(\mathrm{OH}) \mathrm{D} 3$ follows a "u shaped curve", and level more than $150 \mathrm{nM} / \mathrm{L}$ of $25(\mathrm{OH}) \mathrm{D} 3$ are associated with increase of mortality for patients prehospitalised[26].

The level of 1,25(OH)2D3 increase the microbial activity of macrophage and monocyte keratinocytes[25]. Moreover, 1,25(OH)2D3 increase chemotaxis, autophagy, and phagolysosomal fusion of innate immune cells[25]. VD also has a role on adaptive immune system by suppressing its activity and down regulate the production of pro-inflammatory cytokines such interferon-gamma, IL-6, Il-2 and TNF-alpha[25-27] . So a trial testing high dose of VD in tuberculosis treatment shows that it accelerates resolution of inflammatory responses[28].

The whole challenge here is to find the type of VD and the right level of supplementation to achieve the desired effects without toxicity. A high dose of VD 250,000 or 500,000 UI trial in critical care unit ventilated patients with a low rate of VD, reduce hospital length of stay from $36+/-19$ days in control group, $25+/-14$ days in the 250,000 UI group $(25(\mathrm{OH}) \mathrm{D}=45+/ 620 \mathrm{ng} / \mathrm{ml}), 18+/-11$ days in the 500,000 UI group $(25(\mathrm{OH}) \mathrm{D}=55+/-14 \mathrm{ng} / \mathrm{ml})$ [29]. An observational study shows that the rate of 38 $\mathrm{ng} / \mathrm{ml}$ of VD is needed to reduce the risk of community acute pneumonia. The good rate seems to be between $40-60 \mathrm{ng} / \mathrm{ml}$ to have an immune-modulation action [30]

Fortunately, VD appears its toxicity for serum levels in 25-OH VD up to $150 \mathrm{ng} / \mathrm{ml}[31-32]$. However, attention should be paid to possible signs of VD toxicity, such as dehydration, neurological disorders including behavioural disorders and hypercalcaemia in biology.

To achieve the correct rate upper than $50-60 \mathrm{ng} / \mathrm{ml}$ we can use a high dose bolus or a daily intake. A daily intake between 400-1000 UI for infants, 600-4000 UI for children, 1500-10,000 UI for adults, pregnant and lactation [33]. A bolus of $100000 \mathrm{UI}$ is also possible in children[34]. In adulthood a bolus is possible by 200,000 to 500,000 UI [30]. Some study shows that the supplementation of magnesium is need to potentialized the effect of VD and maintain the rate VD in a normal range, because of its role in numerous enzyme reaction[35-36]. A supplementation of magnesium with organic salt as magnesium citrate, gluconate or aspartate at the posology of $5 \mathrm{mg} / \mathrm{kg} /$ day is necessary to improve VD function [37].

\subsubsection{Role of vitamin C}

Known as an anti-scurvy drug, nowadays, vitamin $\mathrm{C}(\mathrm{VC})$ is known to play many functions in organism, like its role in immune system[38-39]. Indeed, many trials tested VC in common cold, show some benefit in healing against infection[38-40-41]. The action of innate, adaptative immune and antibody response is directly correlated with the blood level of VC[42]. The lymphocyte proliferation and activation are enhanced with VC supplementation. VC is accumulated in neutrophils, many trials assessed that neutrophil's chemotaxis, phagocytosis, oxidative burst activity is enhance according with the level of VC [43-44]. VC has a epigenetic property on immune cells, as dendritic cells, monocyte/macrophages, T-cells, NK cells, in modulate maturation, life duration of cell, modulate inflammation mediator[45]. VC application diminishes the secretion of proinflammatory cytokines such as IL-6 and tumor necrosis factor alpha. An oral supplementation increase serum immunoglobulin levels in elderly[46]. Due to this effect on immune system, VC is more and more use for this purpose. In critical care, high dose of VC infusion enhance recovery of inpatient[47]. Indeed, critical ill patients see their VC amount decrease very low, and a correct supplementation is needed to enhance immune system function [48]. In a similar situation, VC supplementation show benefit in winter illness, demonstrate again a function in immune system[49]. In covid19 physiopathology, we assist to a cytokine storm, that is a dysregulation of immune system function. The seriousness of the situation is an acute respiratory distress syndrome. Many studies show that VC high dose diminishes the cytokine storm, enhance the function of immune cells, have a pro-inflammatory action and direct antiviral properties[50]. And this function can use to fight covid19 with great change of success[51]. Richard Z. Cheng have the same hypothesis in high VC use against covid19, showing that an early and adequate dose of infusion of VC, can mitigate mortality and morbidity of covid19[52]. So, on covid19, we can see new trial using high-dose VC with 24 g/day 
infusion for 7 days [53]. Here, the problem to resolve before use VC is the route and doses administration. Indeed, bioavailability of VC in oral route versus parenteral route is different[54]. Oral administration of VC about 1,25g produce a plasma peak concentration at 134,8+/-20,6 4 mol/1 contrarily with a plasma peak at $885+/-201,2 \mu \mathrm{mol} / 1$ with the same dose administered by intravenous route. The maximal oral route doses is $3 \mathrm{~g}$ every 4 hours according to gastroenteric side effect, and the maximal save dose with intravenous route is $1,5 \mathrm{~g} / \mathrm{kg} /$ day [54]. This different between both routes are explained by saturable active transport of VC in intestinal absorption and renal reuptake[55]. The need of VC increases with aggression such infection, smoking or cancer. But we do not know which level of supplementation achieve in viral infection case such as sars-cov-2. According to half-life and clearance of VC in intravenous route, which is $2+/-0,6 \mathrm{~h}$ and $21+/-5 \mathrm{dl} / \mathrm{h} \mathrm{m}^{2}$ [55], maximal concentration is raised to $50 \mathrm{mM}$ for dose between $70-80 \mathrm{~g} / \mathrm{m}^{2}$ to continue infusion[56]. Then a national institute of health expert panel state that high-dose VC at 1,5g/kg/day is saved in person without chronic renal disease and Glucose-6-PhosphateDehydrogenase (G6PD) deficiency[57]. When use high dose of $\mathrm{VC}$, we have to be aware of some issue as oxalate nephropathy, pro-oxidative activity of VC and G6PD deficiency which can lead a red cell haemolysis[58]. Fortunately, these advert effects are rare[59-60]. In more, a synergism is found, in administration of VC, with thiamine and hydrocortisone, due to some metabolism interaction[59]. An association of VC and zinc relieve common cold symptoms and duration[41].

\subsubsection{Role of Zinc}

Zinc is a rare element, that is essential for human metabolism, and this observation was found since 1963[61]. More than 300 enzymes and more than 2000 transcription factors require zinc to function well[61-62]. We know that zinc play too, an important role in immune system[63]. Zinc have an inflammatory, antioxidant and antiviral properties[61-64-65].Intracellular free zinc deficiency mitigate of lipopolysaccharide-mediated CD4+ T-cell activation by dendritic cells[61-66]. Zinc deficiency contribute to increase nuclear factor-kappa B, which increases TNF-alpha and IL-1B[6465]. The development of monocyte/macrophages and their function in phagocytosis, proinflammatory cytokine production is dependent on zinc levels in the organism[67]. Zinc has affected the development of both innate and acquired immune system. Lymphocyte activation, antibody production, intracellular killing and apoptosis of immune cells is affected by zinc deficiency[66-68]. Zinc has a direct action on virus, such as influenza and coronavirus, perhaps through inhibition of RNA-dependent RNA polymerase[69]. It interacts with interferon-lambda3 binding to IFNL receptor 1 on HCV and influenza[70]. So, zinc improves the immune system and has a direct antiviral action on many viruses whose coronavirus. Zinc has demonstrated its action in common cold by reducing the duration of symptoms with a dose up to $75 \mathrm{mg} / \mathrm{day}[71]$. A zinc supplementation trial in elderly decrease the incidence of infection by $66 \%$ and improve cellmediated immunity[62]. Many studies propose to add zinc in protocol against covid19, according to its action on immune system[72-73-74]. A supplementation of $30 \mathrm{mg}$ per day zinc element in infants( 2-60 months) reduces duration of acute lower respiratory tract infections[75]. A metanalyse shows that dose under $75 \mathrm{mg}$ per day of zinc acetate $(22,5 \mathrm{mg}$ zinc element) have no effect on duration of common cold, but a dose upper $75 \mathrm{mg}$ produces $42 \%$ of reduction in duration of common cold[76]. A chronic supplementation of zinc and dose upper than 60-100mg of zinc element per day can produce some side effect and toxicity by diminishing level of cupper and decrease activity of immune system[77].

\subsubsection{Role of selenium}

Selenium is a rare element, but very important compound in the organism, because of its role in multiple reaction in metabolism[78]. Selenium is a cofactor of many enzymes such as glutathione peroxidase or thioredoxin reductase and exerts its functions linked with protein forming selenoprotein[79]. The ideal range of selenium in plasma, according to a U shaped, is 80-120 $\mathrm{gg} / 1[80]$. The selenium has an antioxidant and immune properties[81]. It increases activity of macrophages, production of immunoglobulins, cytolysis of natural killer. The selenium in adequate levels can 
reduce inflammation by lowered expression of pro-inflammatory mediators, including cytokines, redox-sensitive transcription factor NF-kappa B, increase interferon-gamma production[82-83-84]. Furthermore, selenium acts directly in immune system by initiating well function of immunity, regulate excessive immune responses. Supplementing volunteers with $50-100 \mu \mathrm{g} / \mathrm{d}$ increased antipoliovirus and anti-diphtheria immunity[78]. A selenium deficiency under $1 \mu \mathrm{M} / 1$ increase virulence of viruses such as coxsackievirus and decrease immunocompetence of host[79-85-86]. The minimum requirement of selenium according to American recommended dietary allowance is $70 \mu \mathrm{g}$ and $50 \mu \mathrm{g}$

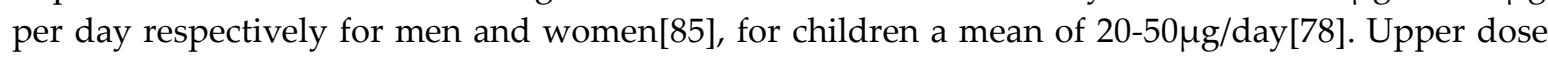
tolerate in supplementation is $400 \mu \mathrm{g} /$ day [87].Then, studies demonstrate that supplementation at $200 \mu \mathrm{g} / \mathrm{day}$, is safe and can be used as adjuvant therapy again virus such as HIV, influenza type A[8286-88]. A recent trial show in China an association between selenium deficiency and covid19 cure rate[89].Toxicity with this element is very rare in recommend supplementation[78]. Selenium excess can be eliminated by urine[90]. But in case of acute poisoning, we can find early symptoms: hypotension, tachycardia, dermatological lesions, hair loss, odour of garlic in the exhaled breath, anaemia , dry cough[81].

\subsubsection{Role of diet nutrition}

More and more, nutrition takes a great place in the field of human health. Nutrition is not only a means to feed, but means to heal too. Nowadays nutrition plays a role in many health problems and it has a link between host's immune system and macro and micronutrient deficiency[91]. "Malnutrition is the primary cause of immunodeficiency worldwide" affecting both innate and adaptative immune system[92].Furthermore western diet affects immune system and correlate with an epidemic inflammatory diseases[93]. Western diet, with its high level of saturated fatty acids, can lead to chronic activation of the innate immune system and inhibition of the adaptative immune system[94].

When immune system is activated, it needs a great level of energy and micronutrients to be functional, for example: fever[95]. Malnutrition impacts the performance of the immune system such as enzyme reaction and immune cell activity. In the way of caloric restriction, it demonstrates that reducing age-associated elevation in cytokines to levels comparable to that of young, and increase concentrations of anti-inflammatory in animals, enhance immune functions[96].

In elderly, protein energy malnutrition decreased immune functions and a refeeding can enhance immunity, but more slowly in inflammatory processes such as infection[97].

We found that the immune system needs macro and micronutrients function well, including vitamins A,D,C,E,B6 and B12, folate, zinc, iron, copper, and selenium [14]. Especially VC and D and zinc have the strongest evidence for immune support[82].

So, a nutritional and dietetics approach must be done to avoid any deficiency in micro and macronutrients. A screening of patients must be done to identify malnutrition risk people to bring them an adequate nutrition supply. This supply must bring $1,5 \mathrm{~g} / \mathrm{kg} / \mathrm{day}$ amino-acid including essential ones, energy $40 \mathrm{kcal} / \mathrm{kg} /$ day, vitamins, unsaturated fat and trace elements support[98].

\section{Discussion}

The emergency of the current situation requires us to propose effective, and easy solutions to eradicate the pandemic worldwide at a lower cost. We believe that, the administration of immunostimulant and immunomodulator therapies, at a very early stage, can stop the spread of this covid19 pandemic and its medical consequences. Our therapeutic proposal is resumed, in table 1, by administration of VD and VC, magnesium, zinc, selenium, nutrition care approach; in specific dosage. To achieve this goal, we propose 2 therapeutics protocols for different intervention groups: a preventive and a curative one. Of course, this treatment protocol does not contraindicate or interferes with a standard care management. It must be used together, for any exposed person to sars-cov-2, suspected or confirmed covid19 patient. 
A preventive intervention group whose aim is to prevent the spread of the disease or occurrence of any asymptomatic forms. This intervention will be given to non-infected people, but potentially exposed people. It is easy to apply on a large scale, with a simple medical monitoring.

A curative intervention group whose aim is to avoid the complication of the disease: embolism, respiratory failure, intensive care supply, death; into infected or suspected people. 
Table 1. therapeutic proposition.

\begin{tabular}{|c|c|c|c|c|}
\hline & Preventive intervention group & \multicolumn{2}{|c|}{ Curative intervention group } & Monitoring \\
\hline & & $\begin{array}{l}\text { No-intensive care needed and } \\
\text { gravity score under 5[99] }\end{array}$ & $\begin{array}{c}\text { Intensive care needed or gravity score } \\
\text { superior or equal 5[99] }\end{array}$ & \\
\hline & Preventive protocol & Curative protocol & Intensive curative protocol & \\
\hline $\begin{array}{l}\text { Vitamin D protocol: } \\
\text { Children up to } 16 \text {-year- } \\
\text { old and adult }\end{array}$ & $\begin{array}{l}\text { Two boluses of } 200,000 \mathrm{UI} \text { per os } \\
\text { separated from } 48 \text { hours, control } \\
\text { serum rate to achieve } 50 \mathrm{ng} / \mathrm{ml} \\
\text { minimum if possible. Then a daily } \\
\text { dose of } 4000 \mathrm{UI} / \text { day until the end of } \\
\text { pandemic }\end{array}$ & $\begin{array}{l}\text { 200,000UI per os every } 48 \text { hours } \\
\text { with serum rate control with a } \\
\text { targets 50-60ng/ml. Then a daily } \\
\text { administration of } 4000 \mathrm{UI} / \text { day }\end{array}$ & $\begin{array}{c}\text { Bolus of 500,000 IU before serum rate } \\
\text { control. Serum control at } 48 \text { hours, if rate } \\
\text { under } 50 \mathrm{ng} / \mathrm{ml} \text {, bolus administration of } \\
200,000 \mathrm{UI} \text { every } 48 \text { hours until a serum } 50- \\
60 \mathrm{ng} / \mathrm{ml} \text {. Then a daily administration of } \\
4000 \mathrm{UI} / \text { day }\end{array}$ & Hypercalcemia, delirium, \\
\hline $\begin{array}{l}\text { Vitamin D protocol: } \\
\text { Infant in children under } \\
\text { 16-year-old }\end{array}$ & $\begin{array}{l}\text { Only a daily dose of } 1000 \mathrm{UI} / \text { day } \\
\text { until the end of pandemic, control } \\
\text { serum rate to achieve } 50 \mathrm{ng} / \mathrm{ml} \\
\text { minimum if possible }\end{array}$ & $\begin{array}{l}\text { Two boluses of } 100,000 \mathrm{UI} \text { per os } \\
\text { separated from } 48 \text { hours, control } \\
\text { serum rate to achieve } 50 \mathrm{ng} / \mathrm{ml} . \\
\text { Then a daily dose of } 2000 \mathrm{UI} / \text { day } \\
\text { until recovery }\end{array}$ & $\begin{array}{l}\text { bolus of 200,000 IU before serum rate } \\
\text { control. Serum control at } 48 \text { hours, if rate } \\
\text { under } 50 \mathrm{ng} / \mathrm{ml} \text {, bolus administration of } \\
\text { 100,000UI every } 48 \text { hours until a serum } 50- \\
60 \mathrm{ng} / \mathrm{ml} \text {. Then a daily administration of } \\
2000 \text { UI/day }\end{array}$ & \\
\hline $\begin{array}{c}\text { Magnesium } \\
\text { supplementation }\end{array}$ & $\begin{array}{l}5 \mathrm{mg} / \mathrm{kg} / \text { day during all the } \\
\text { intervention }\end{array}$ & Idem & idem & $\begin{array}{c}\text { somnolence, muscle paralysis, } \\
\text { flushing, loss of } \\
\text { osteotendinous reflex[100] }\end{array}$ \\
\hline $\begin{array}{l}\text { Vitamin C protocol: } \\
\text { Children up to } 16-\text {-year- } \\
\text { old and adult }\end{array}$ & $\begin{array}{l}3 \mathrm{~g} \text { per os every } 6 \text { hours. the dose } \\
\text { may be reduced to } 2 \mathrm{~g} \text { per intake in } \\
\text { case of gastric discomfort }\end{array}$ & $\begin{array}{l}\text { continuous intravenous infusion } \\
\text { with } 0,5 \mathrm{~g} / \mathrm{kg} / \text { day }\end{array}$ & $\begin{array}{l}\text { Continuous intravenous infusion with } \\
\qquad 1,5 \mathrm{~g} / \mathrm{kg} / \text { day }\end{array}$ & $\begin{array}{l}\text { Urolithiasis } \\
\text { Haemolysis } \\
\text { Icteria }\end{array}$ \\
\hline $\begin{array}{l}\text { Vitamin C protocol: } \\
\text { Infant in children under } \\
\text { 16-year-old }\end{array}$ & $\begin{array}{c}0,5 \mathrm{~g} / \mathrm{kg} / \text { day taken } 4 \text { times a day, } \\
\text { without exceeding } 3 \mathrm{~g} \text { by taken. } \\
\text { dose may be reduced in case of } \\
\text { gastric discomfort }\end{array}$ & $\begin{array}{c}\text { continuous intravenous infusion } \\
\text { with } 0,5 \mathrm{~g} / \mathrm{kg} / \text { day }\end{array}$ & $\begin{array}{l}\text { Continuous intravenous infusion with } \\
\qquad 1,5 \mathrm{~g} / \mathrm{kg} / \text { day }\end{array}$ & \\
\hline $\begin{array}{c}\text { Zinc element } \\
\text { supplementation: } \\
\text { In paediatric and adult } \\
\text { population } \\
\end{array}$ & $30 \mathrm{mg}$ per os & Idem & idem & $\begin{array}{l}\text { Nausea, vomiting epigastric } \\
\text { pain, lethargy, fatigue, } \\
\text { anaemia, dehydration }\end{array}$ \\
\hline
\end{tabular}


Selenium

supplementation:

$\begin{array}{llll}\text { Children up to 16-year- } & 200 \mu \mathrm{g} / \text { day } & \text { Idem } & \text { idem }\end{array}$

old and adult

hypotension, tachycardia, dermatological lesions, hair Selenium

supplementation: Infant in children under 16year-old

an adequate nutrition supply with

$1,5 \mathrm{~g} / \mathrm{kg} /$ day amino-acid including

$$
\text { essential ones, energy } 40
$$

$\mathrm{kcal} / \mathrm{kg} /$ day, vitamins, unsaturated

Idem

idem fat and trace elements

Decryption of nutrients and posology in the aim to enhance the immun system. 


\section{Conclusions}

The spread of the covid19 pandemic will lead to a review of our health systems organisation, our way of thinking, but also of the way we deal with emerging new pathogens. Considering the seriousness of the situation, any research leads should not be discarded. Our point of view, although off the beaten track, is very promising and hopeful. It deserves its place in a clinical trial such as other approaches already tested.

Conflicts of Interest: The authors declare no conflict of interest.

Authors' contribution: Louis Sylvain Peng-wende Ouedraogo contributed to the conception, and design of the research, acquisition and analysis of the data; Louis Sylvain Peng-wende Ouedraogo, Sodjehoun Apeti, Dieudonné Ouedraogo equally contributed to the interpretation of the data; Louis Sylvain Peng-wende Ouedraogo and Sodjehoun Apeti drafted the manuscript. All authors critically revised the manuscript, agree to be fully accountable for ensuring the integrity and accuracy of the work, and read and approved the final manuscript.

Acknowledgments: To Nadège Ilboudo for her special technical support on translation and correction.

Funding: This research did not receive any specific grant from funding agencies in the public, commercial, or not-for-profit sectors.

\section{References}

1. Ren L-L, Wang Y-M, Wu Z-Q, Xiang Z-C, Guo L, Xu T, et al. Identification of a novel coronavirus causing severe pneumonia in human: a descriptive study. Chinese Medical Journal. doi:10.1097/CM9.0000000000000722.

2. Lu H, Stratton CW, Tang Y-W. Outbreak of pneumonia of unknown etiology in Wuhan, China: The mystery and the miracle. Journal of Medical Virology. 2020;92(4):401.

3. Bogoch II, Watts A, Thomas-Bachli A, Huber C, Kraemer MUG, Khan K. Pneumonia of unknown aetiology in Wuhan, China: potential for international spread via commercial air travel. Journal of Travel Medicine. 2020;27(2). doi:10.1093/jtm/taaa008.

4. WHO Director-General's opening remarks at the media briefing on COVID-19 - 13 April 2020. https://www.who.int/dg/speeches/detail/who-director-general-s-opening-remarks-at-the-mediabriefing-on-covid-19--13-april-2020. Accessed 25 April 2020.

5. Louis Pasteur. Wikipedia.

2020. https://en.wikipedia.org/w/index.php?title=Louis_Pasteur\&oldid=952255030. Accessed 25 April 2020.

6. Alexander Fleming. 2020. https://en.wikipedia.org/w/index.php?title=Alexander_Fleming\&oldid=951701985. Accessed 25 April 2020.

7. Canouï E, Launay O. [History and principles of vaccination]. Rev Mal Respir. 2019;36(1):74-81.

8. Trial of Treatments for COVID-19 in Hospitalized Adults - Full Text View - ClinicalTrials.gov. https://clinicaltrials.gov/ct2/show/NCT04315948. Accessed 25 April 2020.

9. Treatments for COVID-19: Canadian Arm of the SOLIDARITY Trial - Full Text View - ClinicalTrials.gov. https://clinicaltrials.gov/ct2/show/NCT04330690. Accessed 25 April 2020.

10. El-Aziz TMA, Stockand JD. Recent progress and challenges in drug development against COVID-19 coronavirus (SARS-CoV-2) - an update on the status. Infect Genet Evol. 2020. doi:10.1016/j.meegid.2020.104327.

11. Ranucci M, Ballotta A, Di Dedda U, Bayshnikova E, Dei Poli M, Resta M, et al. The procoagulant pattern of patients with COVID-19 acute respiratory distress syndrome. J Thromb Haemost. 2020. doi:10.1111/jth.14854. 
12. Klok FA, Kruip MJHA, van der Meer NJM, Arbous MS, Gommers D a. MPJ, Kant KM, et al. Incidence of thrombotic complications in critically ill ICU patients with COVID-19. Thromb Res. 2020. doi:10.1016/j.thromres.2020.04.013.

13. Jin Y, Yang H, Ji W, Wu W, Chen S, Zhang W, et al. Virology, Epidemiology, Pathogenesis, and Control of COVID-19. Viruses. 2020;12(4):372.

14. Calder PC, Carr AC, Gombart AF, Eggersdorfer M. Optimal Nutritional Status for a Well-Functioning Immune System Is an Important Factor to Protect against Viral Infections. Nutrients. 2020;12(4):1181.

15. Fox SJ, Miller JC, Meyers LA. Seasonality in risk of pandemic influenza emergence. PLOS Computational Biology. 2017;13(10):e1005749.

16. (PDF) Annual Review of Virology Seasonality of Respiratory Viral Infections. ResearchGate. https://www.researchgate.net/publication/340377598_Annual_Review_of_Virology_Seasonality_of_Resp iratory_Viral_Infections. Accessed 27 April 2020.

17. Saha S, Chadha M, Shu Y, Lijie W, Chittaganpitch M, Waicharoen S, et al. Divergent seasonal patterns of influenza types A and B across latitude gradient in Tropical Asia. Influenza Other Respir Viruses. 2016;10(3):176-184.

18. Bloom-Feshbach K, Alonso WJ, Charu V, Tamerius J, Simonsen L, Miller MA, et al. Latitudinal variations in seasonal activity of influenza and respiratory syncytial virus (RSV): a global comparative review. PLoS ONE. 2013;8(2):e54445.

19. Sooryanarain H, Elankumaran S. Environmental Role in Influenza Virus Outbreaks. Annual Review of Animal Biosciences. 2015;3(1):347-373.

20. A J, Lw M, M K, Ga P, Z L, A D, et al. The Seasonality of Pandemic and Non-Pandemic Influenzas: The Roles of Solar Radiation and Vitamin D. International journal of infectious diseases: IJID : official publication of the International Society for Infectious Diseases. 2010;14(12). doi:10.1016/j.ijid.2010.09.002.

21. Rhodes JM, Subramanian S, Laird E, Kenny RA. Editorial: low population mortality from COVID-19 in countries south of latitude 35 degrees North supports vitamin D as a factor determining severity. Alimentary Pharmacology \& Therapeutics.n/a(n/a). doi:10.1111/apt.15777.

22. Zmijewski MA. Vitamin D and Human Health. International Journal of Molecular Sciences. 2019;20(1). doi:10.3390/ijms20010145.

23. Prietl B, Treiber G, Pieber TR, Amrein K. Vitamin D and Immune Function. Nutrients. 2013;5(7):25022521.

24. Sharifi A, Vahedi H, Nedjat S, Rafiei H, Hosseinzadeh-Attar MJ. Effect of single-dose injection of vitamin $\mathrm{D}$ on immune cytokines in ulcerative colitis patients: a randomized placebo-controlled trial. APMIS. 2019;127(10):681-687.

25. Sassi F, Tamone C, D'Amelio P. Vitamin D: Nutrient, Hormone, and Immunomodulator. Nutrients. 2018;10(11). doi:10.3390/nu10111656.

26. Amrein K, Quraishi SA, Litonjua AA, Gibbons FK, Pieber TR, Camargo CA, et al. Evidence for a U-Shaped Relationship Between Prehospital Vitamin D Status and Mortality: A Cohort Study. J Clin Endocrinol Metab. 2014;99(4):1461-1469.

27. Cantorna MT, Snyder L, Lin Y-D, Yang L. Vitamin D and 1,25(OH)2D Regulation of T cells. Nutrients. 2015;7(4):3011.

28. Coussens AK, Wilkinson RJ, Hanifa Y, Nikolayevskyy V, Elkington PT, Islam K, et al. Vitamin D accelerates resolution of inflammatory responses during tuberculosis treatment. Proc Natl Acad Sci U S A. 2012;109(38):15449-15454. 
29. Han JE, Jones JL, Tangpricha V, Brown MA, Brown LAS, Hao L, et al. High Dose Vitamin D Administration in Ventilated Intensive Care Unit Patients: A Pilot Double Blind Randomized Controlled Trial. J Clin Transl Endocrinol. 2016;4:59-65.

30. Grant WB, Lahore H, McDonnell SL, Baggerly CA, French CB, Aliano JL, et al. Evidence that Vitamin D Supplementation Could Reduce Risk of Influenza and COVID-19 Infections and Deaths. Nutrients. 2020;12(4):988.

31. Galior K, Grebe S, Singh R. Development of Vitamin D Toxicity from Overcorrection of Vitamin D Deficiency: A Review of Case Reports. Nutrients. 2018;10(8). doi:10.3390/nu10080953.

32. Lee JP, Tansey M, Jetton JG, Krasowski MD. Vitamin D Toxicity: A 16-Year Retrospective Study at an Academic Medical Center. Lab Med. 2018;49(2):123-129.

33. Holick MF, Binkley NC, Bischoff-Ferrari HA, Gordon CM, Hanley DA, Heaney RP, et al. Evaluation, Treatment, and Prevention of Vitamin D Deficiency: an Endocrine Society Clinical Practice Guideline. J Clin Endocrinol Metab. 2011;96(7):1911-1930.

34. Ducharme FM, Jensen M, Mailhot G, Alos N, White J, Rousseau E, et al. Impact of two oral doses of 100,000 IU of vitamin D3 in preschoolers with viral-induced asthma: a pilot randomised controlled trial. Trials. 2019;20. doi:10.1186/s13063-019-3184-z.

35. Dai Q, Zhu X, Manson JE, Song Y, Li X, Franke AA, et al. Magnesium status and supplementation influence vitamin $\mathrm{D}$ status and metabolism: results from a randomized trial. Am J Clin Nutr. 2018;108(6):1249-1258.

36. Reddy P, Edwards LR. Magnesium Supplementation in Vitamin D Deficiency. Am J Ther. 2019;26(1):e124e132.

37. Gröber U, Schmidt J, Kisters K. Magnesium in Prevention and Therapy. Nutrients. 2015;7(9):8199-8226.

38. Hemilä H. Vitamin C and Infections. Nutrients. 2017;9(4). doi:10.3390/nu9040339.

39. Thomas WR, Holt PG. Vitamin C and immunity: an assessment of the evidence. Clin Exp Immunol. 1978;32(2):370-379.

40. Colunga Biancatelli RML, Berrill M, Marik PE. The antiviral properties of vitamin C. Expert Review of Anti-infective Therapy. 2020;18(2):99-101.

41. Maggini S, Beveridge S, Suter M. A Combination of High-Dose Vitamin C plus Zinc for the Common Cold: Journal of International Medical Research. 2012. doi:10.1177/147323001204000104.

42. Webb AL, Villamor E. Update: Effects of Antioxidant and Non-Antioxidant Vitamin Supplementation on Immune Function. Nutr Rev. 2007;65(5):181-217.

43. Liugan M, Carr AC. Vitamin C and Neutrophil Function: Findings from Randomized Controlled Trials. Nutrients. 2019;11(9). doi:10.3390/nu11092102.

44. Carr AC, Maggini S. Vitamin C and Immune Function. Nutrients. 2017;9(11). doi:10.3390/nu9111211.

45. Ang A, Pullar JM, Currie MJ, Vissers MCM. Vitamin C and immune cell function in inflammation and cancer. Biochem Soc Trans. 2018;46(5):1147-1159.

46. Jayachandran M, Rani PJA, Arivazhagan P, Panneerselvam C. Neutrophil Phagocytic Function and Humoral Immune Response with Reference to Ascorbate Supplementation in Aging Humans. Journal of Anti-Aging Medicine. 2000;3(1):37-42.

47. Spoelstra-de Man AME, Elbers PWG, Oudemans-van Straaten HM. Making sense of early high-dose intravenous vitamin C in ischemia/reperfusion injury. Crit Care. 2018;22. doi:10.1186/s13054-018-1996-y. 
48. Carr AC, Rosengrave PC, Bayer S, Chambers S, Mehrtens J, Shaw GM. Hypovitaminosis C and vitamin C deficiency in critically ill patients despite recommended enteral and parenteral intakes. Crit Care. 2017;21. doi:10.1186/s13054-017-1891-y.

49. Anderson TW, Beaton GH, Corey P, Spero L. Winter illness and vitamin C: the effect of relatively low doses. Can Med Assoc J. 1975;112(7):823-826.

50. Boretti A, Banik BK. Intravenous vitamin C for reduction of cytokines storm in acute respiratory distress syndrome. PharmaNutrition. 2020;12:100190.

51. Kakodkar P, Kaka N, Baig M. A Comprehensive Literature Review on the Clinical Presentation, and Management of the Pandemic Coronavirus Disease 2019 (COVID-19). Cureus.12(4). doi:10.7759/cureus.7560.

52. Cheng RZ. Can early and high intravenous dose of vitamin C prevent and treat coronavirus disease 2019 (COVID-19)? Med Drug Discov. 2020;5:100028.

53. Carr AC. A new clinical trial to test high-dose vitamin C in patients with COVID-19. Crit Care. 2020;24. doi:10.1186/s13054-020-02851-4.

54. Padayatty SJ, Sun H, Wang Y, Riordan HD, Hewitt SM, Katz A, et al. Vitamin C pharmacokinetics: implications for oral and intravenous use. Ann Intern Med. 2004;140(7):533-537.

55. Lykkesfeldt J, Tveden-Nyborg P. The Pharmacokinetics of Vitamin C. Nutrients. 2019;11(10). doi:10.3390/nu11102412.

56. Stephenson CM, Levin RD, Spector T, Lis CG. Phase I clinical trial to evaluate the safety, tolerability, and pharmacokinetics of high-dose intravenous ascorbic acid in patients with advanced cancer. Cancer Chemother Pharmacol. 2013;72(1):139-146.

57. High-Dose Vitamin C (PDQ®)-Health Professional Version - National Cancer Institute. 2013. https://www.cancer.gov/about-cancer/treatment/cam/hp/vitamin-c-pdq. Accessed 10 May 2020.

58. Vitamin C toxicity. Nutr Rev. 1976;34(8):236-237.

59. Spoelstra-de Man AME, Elbers PWG, Oudemans-Van Straaten HM. Vitamin C: should we supplement? Curr Opin Crit Care. 2018;24(4):248-255.

60. Berger MM. Vitamin C requirements in parenteral nutrition. Gastroenterology. 2009;137(5 Suppl):S70-78.

61. Prasad AS. Discovery of Human Zinc Deficiency: Its Impact on Human Health and Disease. Adv Nutr. 2013;4(2):176-190.

62. Prasad AS. Discovery of Zinc for Human Health and Biomarkers of Zinc Deficiency. Molecular, Genetic, and Nutritional Aspects of Major and Trace Minerals. 2017;241-260.

63. Wessels I, Maywald M, Rink L. Zinc as a Gatekeeper of Immune Function. Nutrients. 2017;9(12). doi:10.3390/nu9121286.

64. Jarosz M, Olbert M, Wyszogrodzka G, Młyniec K, Librowski T. Antioxidant and anti-inflammatory effects of zinc. Zinc-dependent NF-кB signaling. Inflammopharmacology. 2017;25(1):11-24.

65. Gammoh NZ, Rink L. Zinc in Infection and Inflammation. Nutrients. 2017;9(6). doi:10.3390/nu9060624.

66. Maywald M, Wessels I, Rink L. Zinc Signals and Immunity. Int J Mol Sci. 2017;18(10). doi:10.3390/ijms18102222.

67. Haase H, Rink L. Signal transduction in monocytes: the role of zinc ions. Biometals. 2007;20(3-4):579-585. 
68. Shankar AH, Prasad AS. Zinc and immune function: the biological basis of altered resistance to infection. Am J Clin Nutr. 1998;68(2 Suppl):447S-463S.

69. Read SA, Obeid S, Ahlenstiel C, Ahlenstiel G. The Role of Zinc in Antiviral Immunity. Adv Nutr. 2019;10(4):696-710.

70. Read SA, O'Connor KS, Suppiah V, Ahlenstiel CLE, Obeid S, Cook KM, et al. Zinc is a potent and specific inhibitor of IFN- $\lambda 3$ signalling. Nat Commun. 2017;8. doi:10.1038/ncomms15245.

71. Singh M, Das RR. Zinc for the common cold. Cochrane Database Syst Rev. 2015;2015(4). doi:10.1002/14651858.CD001364.pub5.

72. Derwand R, Scholz M. Does zinc supplementation enhance the clinical efficacy of chloroquine/hydroxychloroquine to win todays battle against COVID-19? Med Hypotheses. 2020. doi:10.1016/j.mehy.2020.109815.

73. Zhang L, Liu Y. Potential interventions for novel coronavirus in China: A systematic review. J Med Virol. 2020;92(5):479-490.

74. Brasiel PG de A. The key role of zinc in elderly immunity: A possible approach in the COVID-19 crisis. Clinical Nutrition ESPEN. 2020;38:65-66.

75. Rerksuppaphol S, Rerksuppaphol L. A randomized controlled trial of zinc supplementation in the treatment of acute respiratory tract infection in Thai children. Pediatr Rep. 2019;11(2). doi:10.4081/pr.2019.7954.

76. Hemilä H, Petrus EJ, Fitzgerald JT, Prasad A. Zinc acetate lozenges for treating the common cold: an individual patient data meta-analysis. Br J Clin Pharmacol. 2016;82(5):1393-1398.

77. Fosmire GJ. Zinc toxicity. Am J Clin Nutr. 1990;51(2):225-227.

78. Prabhu KS, Lei XG. Selenium12. Adv Nutr. 2016;7(2):415-417.

79. Duntas LH, Benvenga S. Selenium: an element for life. Endocrine. 2015;48(3):756-775.

80. Rayman MP, Stranges S. Epidemiology of selenium and type 2 diabetes: can we make sense of it? Free Radic Biol Med. 2013;65:1557-1564.

81. Kieliszek M. Selenium-Fascinating Microelement, Properties and Sources in Food. Molecules. 2019;24(7). doi:10.3390/molecules24071298.

82. Gombart AF, Pierre A, Maggini S. A Review of Micronutrients and the Immune System-Working in Harmony to Reduce the Risk of Infection. Nutrients. 2020;12(1). doi:10.3390/nu12010236.

83. Mehdi Y, Hornick J-L, Istasse L, Dufrasne I. Selenium in the Environment, Metabolism and Involvement in Body Functions. Molecules. 2013;18(3):3292-3311.

84. Huang Z, Rose AH, Hoffmann PR. The Role of Selenium in Inflammation and Immunity: From Molecular Mechanisms to Therapeutic Opportunities. Antioxid Redox Signal. 2012;16(7):705-743.

85. Shreenath AP, Dooley J. Selenium Deficiency. In: StatPearls. 2020. Treasure Island (FL). StatPearls Publishing http://www.ncbi.nlm.nih.gov/books/NBK482260/. Accessed 15 May 2020.

86. Steinbrenner H, Al-Quraishy S, Dkhil MA, Wunderlich F, Sies H. Dietary Selenium in Adjuvant Therapy of Viral and Bacterial Infections12. Adv Nutr. 2015;6(1):73-82.

87. Wang N, Tan H-Y, Li S, Xu Y, Guo W, Feng Y. Supplementation of Micronutrient Selenium in Metabolic Diseases: Its Role as an Antioxidant. Oxid Med Cell Longev. 2017;2017. doi:10.1155/2017/7478523. 
88. Guillin OM, Vindry C, Ohlmann T, Chavatte L. Selenium, Selenoproteins and Viral Infection. Nutrients. 2019;11(9). doi:10.3390/nu11092101.

89. Zhang J, Taylor EW, Bennett K, Saad R, Rayman MP. Association between regional selenium status and reported outcome of COVID-19 cases in China. Am J Clin Nutr. 2020. doi:10.1093/ajcn/nqaa095.

90. Combs GF. Biomarkers of Selenium Status. Nutrients. 2015;7(4):2209-2236.

91. Veldhoen M, Veiga-Fernandes H. Feeding immunity: skepticism, delicacies and delights. Nat Immunol. 2015;16(3):215-219.

92. Alwarawrah Y, Kiernan K, MacIver NJ. Changes in Nutritional Status Impact Immune Cell Metabolism and Function. Front Immunol. 2018;9. doi:10.3389/fimmu.2018.01055.

93. Maslowski KM, Mackay CR. Diet, gut microbiota and immune responses. Nat Immunol. 2011;12(1):5-9.

94. Butler MJ, Barrientos RM. The impact of nutrition on COVID-19 susceptibility and long-term consequences. Brain Behav Immun. 2020. doi:10.1016/j.bbi.2020.04.040.

95. Childs CE, Calder PC, Miles EA. Diet and Immune Function. Nutrients. 2019;11(8). doi:10.3390/nu11081933.

96. Hale MW, Spencer SJ, Conti B, Jasoni CL, Kent S, Radler ME, et al. Diet, behaviour and immunity across the lifespan. Neuroscience and biobehavioral reviews. 2015;58:46.

97. Lesourd B. Nutrition: a major factor influencing immunity in the elderly. J Nutr Health Aging. 2004;8(1):28-37.

98. Briguglio M, Pregliasco FE, Lombardi G, Perazzo P, Banfi G. The Malnutritional Status of the Host as a Virulence Factor for New Coronavirus SARS-CoV-2. Front Med (Lausanne). 2020;7. doi:10.3389/fmed.2020.00146.

99. Liao X, Wang B, Kang Y. Novel coronavirus infection during the 2019-2020 epidemic: preparing intensive care units - the experience in Sichuan Province, China. Intensive Care Med. 2020;46(2):357-360.

100. Ajib FA, Childress JM. Magnesium Toxicity. In: StatPearls. 2020. Treasure Island (FL). StatPearls Publishing http://www.ncbi.nlm.nih.gov/books/NBK554593/. Accessed 9 May 2020. 